Hydrol. Earth Syst. Sci., 17, 2515-2527, 2013

www.hydrol-earth-syst-sci.net/17/2515/2013/

doi:10.5194/hess-17-2515-2013

(c) Author(s) 2013. CC Attribution 3.0 License.

\title{
Runoff and Sediment load of the Yan River, China: changes over the last $60 \mathrm{yr}$
}

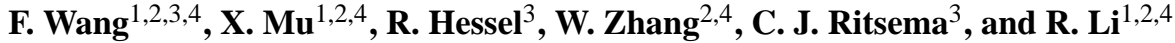 \\ ${ }^{1}$ State Key Laboratory of Soil Erosion and Dryland Farming on the Loess Plateau, Institute of Soil and Water Conservation, \\ Northwest A\&F University, Yangling 712100, Shaanxi, China \\ ${ }^{2}$ Institute of Soil and Water Conservation, Chinese Academy of Sciences and Ministry of water Resources, \\ Yangling 712100, Shaanxi, China \\ ${ }^{3}$ Alterra, Wageningen University and Research Centre, P.O. Box 47, 6700 AA Wageningen, the Netherlands \\ ${ }^{4}$ University of Chinese Academy of Sciences, Beijing 100049, China
}

Correspondence to: F. Wang (wafe@ms.iswc.ac.cn)

Received: 6 December 2012 - Published in Hydrol. Earth Syst. Sci. Discuss.: 25 January 2013

Revised: 3 June 2013 - Accepted: 3 June 2013 - Published: 5 July 2013

\begin{abstract}
Runoff and sediment load changes are affected by climate change and human activities in an integrated way. Historical insight into these effects can not only improve the knowledge of river processes, but also promote more effective land and water management. In this study, we looked at runoff and sediment change in the Yan River basin, Loess Plateau, China, using data sets on land use and land cover (LUC), monthly data of precipitation and temperature, and observed data on runoff and sediment load from 1952 to 2010 at the Ganguyi Hydrologic Station. Available data on soil and water conservation structures and their effect were also studied. Five main findings emerged from the data analysis. (1) The annual runoff and sediment load varied greatly during the last $60 \mathrm{yr}$, and both had coefficients of variation that were much larger than those of precipitation and temperature. (2) Annual runoff and sediment load both showed a significant trend of linear decline over the period studied. The climate data showed a non-significant decline in precipitation over the same period, and a very significant increase in temperature; both can help explain the observed declines in runoff and soil loss. (3) Based on a mass curve analysis with anomalies of normalized runoff and sediment load, 4 stages in the change of runoff and soil loss were identified: 1951 to 1971 (Stage I), 1972 to 1986 (Stage II), 1987 to 1996 (Stage III) and 1997 to 2010 (Stage IV). (4) When years were paired based on similar precipitation and temperature condition (SPTC) and used to assess the impacts of human activities, it was found that 6 sets of paired years out of $12(50 \%)$
\end{abstract}

showed a decline in runoff, $8(67 \%)$ a decline in sediment load, and $9(75 \%)$ a decline in sediment concentration. The other sets show an increasing change with time. It showed the complexity of human impacts. (5) Human impacts relating to LUC change and soil and water measures in this basin were significant because of both the transfer of sloping cropland into non-food vegetation or terraces, and the siltation in the reservoirs and behind check dams. Data indicated that about 56 Mt of sediment was deposited annually from 1960 1999 as a result of the soil and water conservation structures, which is significantly more than the average $42 \mathrm{Mt}$, leaving the Yan River basin as sediment load each year. Although the effects of climate change and human action could not be separated, analysis of the data indicated that both had a significant impact on runoff and sediment load in the area.

\section{Introduction}

The Yellow River is China's second largest river, and derives its name from the sediment suspended in its waters. These sediment contents pose a major problem because sedimentation in the lower course of the river has raised the river bed to several meters above the surrounding landscape (Douglas, 1989; Zhang et al., 1990; Zhu et al., 1997), and reservoirs are being filled with sediment (e.g Wan and Wang, 1994). The Chinese government is committed to combatting these problems and much attention is being directed at decreasing 
the erosion rates on the Loess Plateau, as it is the source of about $90 \%$ of all the sediment that enters the Yellow River (Douglas, 1989; Wan and Wang, 1994). The Loess Plateau has some of the highest erosion rates on the entire planet. Jiang et al. (1981) estimated that erosion rates may be as much as $18000 \mathrm{t}$ per square kilometer per year for the hilly loess region of the Wuding River basin, which is one of the main Loess Plateau tributaries of the Yellow River. Sediment concentrations in runoff on the Loess Plateau of over $1000 \mathrm{~kg} \mathrm{~m}^{-3}$ have been recorded regularly (e.g. Jiang et al., 1981; Zhang et al., 1990; Wan and Wang, 1994).

To effectively combat erosion on the Loess Plateau, it is important to have insight into the historical development of runoff and sediment yield, and causes of significant changes. In particular, it is important to know to what degree the main causes are related to climate or to human activity, e.g. through land use change and through building of reservoirs. Where human activity is a main contributing factor, there will be opportunities for reducing discharge and soil loss through modified activity, for example changes in land use.

Ren and Zhu (1994) showed how different kinds of information (written records, Yellow River delta volumes) indicate that the serious soil erosion on the Loess Plateau started around $1000 \mathrm{AD} . \mathrm{Xu}$ (2001) found that bank breaching of the Yellow River increased in frequency from the 10th century AD onwards. According to him, breaching frequency depends on sediment load, which apparently increased due to increased erosion on the Loess Plateau following destruction of the natural vegetation. On the other hand, Long and Xiong (1981) reported that historic literature from the Eastern Han Dynasty (25-220 AD) already recorded very high sediment contents: "the silt occupied six tenths of the volume in one barrel of water sampled" (Long and Xiong, 1981). According to Peng et al. (2010) sediment yield started to increase around $3000 \mathrm{BP}$ (1050 BC) because of cultivation and deforestation, but abruptly increased further around $1000 \mathrm{AD}$ to levels that were maintained until the 1950s.

Monitoring of the Yellow River and its tributaries on the Loess Plateau started in the 1950s and has shown a gradual decrease over the years in runoff as well as sediment load (e.g. Peng et al., 2010). Several authors have recently studied changes in discharge, sediment load and climate and have tried to quantify the contribution of climate variability and human action to the observed changes. Li et al. (2009) studied the Hei River basin and reported that over the period 1981-2000 climate variability influenced discharge and sediment yield more than land use change. However, this might be due to the relatively limited changes in land use during this period; much larger land use changes have occurred since 2000 as a result of the "Grain for Green" project (Feng et al., 2010; Wang et al., 2010; Miao et al., 2011). Other studies have indicated that land use changes, i.e. human activity, can have significant effects on runoff and soil loss on the Loess Plateau (e.g. Hessel et al., 2003; Zhang et al., 2004; Feng et al., 2010). Furthermore, Peng et al. (2010) reported that the main reason for a decrease in sediment load in the Yellow River is the conservation measures that have been implemented in the middle reaches of the basin since the 1950s; again human activity. Nonetheless, there are climate trends that could also explain the observed decreases in runoff and sediment load. Li et al. (2009) observed a decrease in rainfall and an increase in temperature over the period 1981-2000, and Wang et al. (2012) also reported decreasing rainfall and increasing temperature on the Loess Plateau, over the period 1961-2010. Finally, Miao et al. (2011), who studied the whole Yellow River basin and found a general increase in the influence of human activity over time (even outweighing the influence of climate in the period 2000-2008), also observed varying degrees of influence from climate and human impact for different decades since 1960, and for different parts of the Yellow River. These studies show that climatic variability/change and human action are both important factors to take into account to understand trends in discharge and sediment load on the Loess Plateau. Which of these factors outweighs the other is likely to depend on the area and time period that are studied.

In this paper we look at runoff and sediment yield developments over approximately the last $60 \mathrm{yr}$ in the Yan River, one of the main Loess Plateau tributaries of the Yellow River. As previously mentioned, monitoring of rainfall, discharge and sediment content in the Yan River basin started in 1952; satellite images that can be used to derive information on land use are available from 1980. These and other data sources are used to analyze the trends and the impact that climate and/or human activity has had on the changes.

The aims of this paper are (1) to show how discharge and sediment yield from the Yan River varied over the last $59 \mathrm{yr}$; (2) to compare discharge and sediment load with rainfall data and land use and cover change data to identify causes for the observed changes; and (3) to discuss implications for watershed management.

\section{Materials and methods}

\subsection{Study area}

The Yan River is a first-order branch of the Yellow River, China. The Yan River basin $\left(36^{\circ} 21^{\prime}-37^{\circ} 19^{\prime} \mathrm{N}, 108^{\circ} 38^{\prime}-\right.$ $110^{\circ} 29^{\prime} \mathrm{E}$ ) is located in the middle of the Loess Plateau and the area of the whole basin is $7687 \mathrm{~km}^{2}$. The basin contains parts of 5 counties, namely Jingbian County, Zhidan County, Ansai County, Baota District and Yanchang County of Yan'an City, Shaanxi Province (Fig. 1).

The climate region of the Yan River basin is north temperate continental monsoonal, with average annual precipitation varying from 500 to $550 \mathrm{~mm}$ and average annual air temperature ranging from 8.5 to $11.4^{\circ} \mathrm{C}$ (Wang et al., 2010). The study area is covered by thick erosion-prone loess, a type of fine silt soil ( $\mathrm{Fu}$ and Gulinck, 1994). Soil loss is 


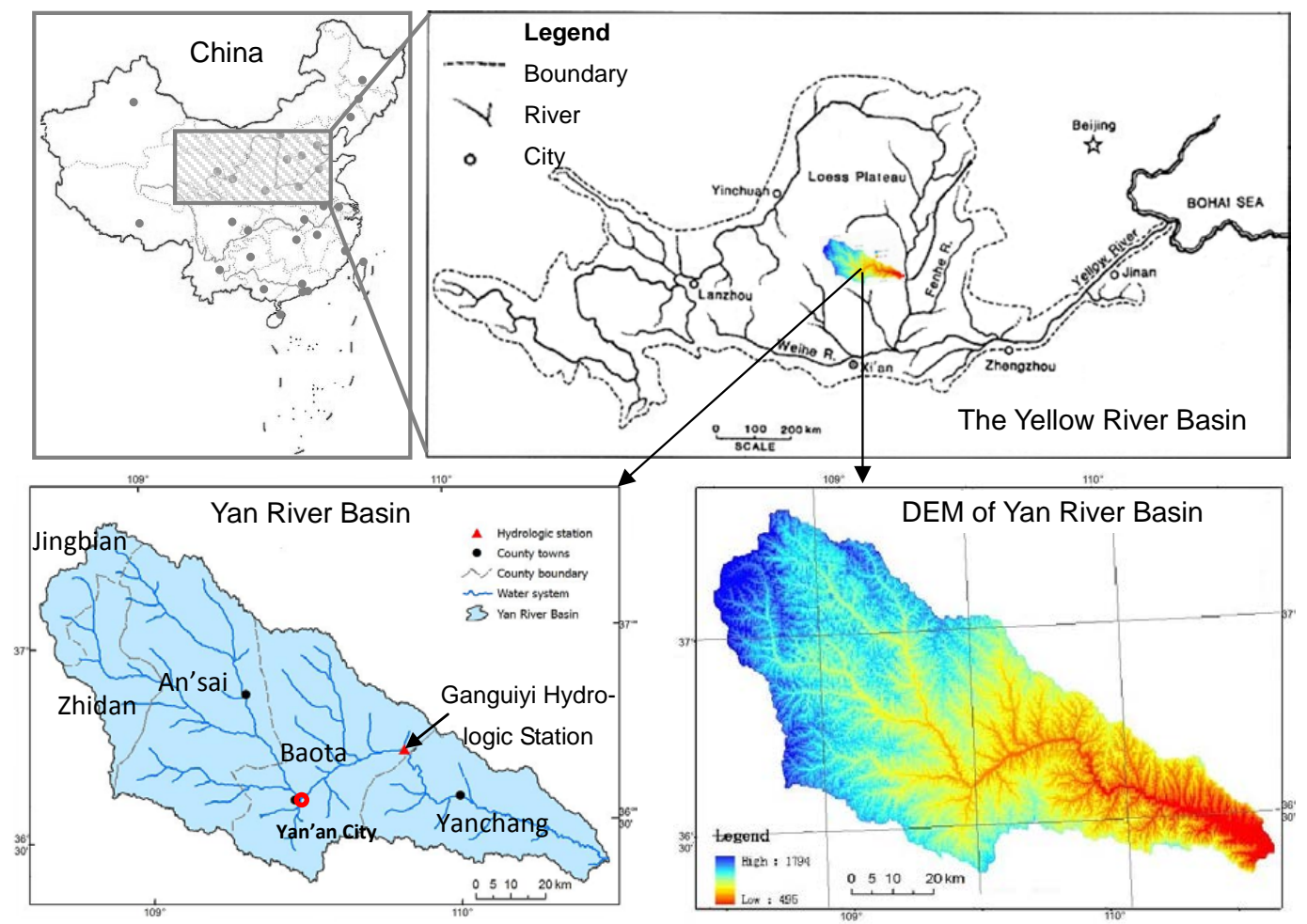

Fig. 1. Location of the study area (the Yan River basin, China).

severe throughout the basin and causes enormous sedimentation and high flood risks downstream, including in the Yellow River (Hessel et al., 2003). The landform is heavily dissected due to long-term soil erosion and the gully density (the total length of channel in one $\mathrm{km}^{2}$ ) ranges from 2.1 to $4.6 \mathrm{~km} \mathrm{~km}^{-2}$ (Wang et al., 2005).

The Ganguyi Hydrologic Station (GHS, $109^{\circ} 48^{\prime} \mathrm{E}$, $36^{\circ} 42^{\prime} \mathrm{N}$ ) is located in Ganguyi Town, Baota County. Its control area is $5891 \mathrm{~km}^{2}$, including Jingbian County $\left(256 \mathrm{~km}^{2}\right)$, Zhidan County $\left(708 \mathrm{~km}^{2}\right)$, Ansai County $\left(2699 \mathrm{~km}^{2}\right)$ and Baota District $\left(2228 \mathrm{~km}^{2}\right)$ (Fig. 1). The average annual runoff and sediment load were 203.5 million $\mathrm{m}^{3}\left(\mathrm{M} \mathrm{m}^{3}\right)$ and 41.5 million tons $(\mathrm{Mt})$, respectively from 1952-2010. The average sediment concentration was $204 \mathrm{~kg} \mathrm{~m}^{-3}$ and the sediment load module was $7040 \mathrm{t} \mathrm{km}^{-2} \mathrm{yr}^{-1}$ (Ministry of Water Resources of China, 2011).

\subsection{Data}

A $59 \mathrm{yr}$ dataset of precipitation, temperature, runoff and sediment load from 1952 to 2010 was analyzed. Climate data were obtained from the 6 county level meteorological stations of Yan' an City which is located in the middle of the Yan River basin (Fig. 1). Precipitation (including total precipitation of each year (a.pptn, in $\mathrm{mm}$ ) and precipitation in the rainy season from May to October (r.pptn), in $\mathrm{mm}$ ) and annual mean, maximum and minimum air temperature $\left(t, t_{\max }\right.$, $t_{\min }$, respectively, in ${ }^{\circ} \mathrm{C}$ ) were the spatially averaged data based on the daily records of stations upstream area of GHS (A-GHS) using the Thiessen polygon method. The observation and data management was according to the specifications for surface meteorological observation of China (China Meteorological Administration, 2003). The annual runoff (in $\mathrm{M} \mathrm{m}^{3}$ ) and sediment load (in $\mathrm{Mt}$ ) data were derived from the daily monitoring records at GHS with water level and flow velocity of river section for runoff and sediment sample measurements according the national standards of China on measurement of suspended sediment and flow in open channels (State Quality Supervision Bureau and Ministry of Construction of China, 1992, 1993). The strong rainfall events are the main natural driving forces of soil erosion and sediment load in the Loess Plateau (Hessel et al., 2003; Li et al., 2010; Miao et al., 2011). Most of precipitation occurs in the rainy season from May to October (Li et al., 2010; Miao et al., 2011) in highly localized events. As we are looking at the scale of the whole Yan River basin based on time series at that scale, we used the annual precipitation for our analysis.

The Land Use and Land Cover (LUC) data was obtained from the Data Sharing Infrastructure of Earth System Science, National Scientific Data Shared Platform (www. geodata.cn). LUC includes 5 digital maps from 1980, 1985, 1996, 2000 to 2005. The map scale in 1985, 1996 and 2000 was $1: 100000$ and in 1980 and 2005 it was $1: 250000$. The series of map could describe the LUC change. The maps with 
larger scale were used to evaluate the total change over time, but they could not show very fine information and affected the detail, particularly of the built-up area information. The classification procedure was based on image interpretation combined with field investigation. LUC was classified into 6 categories as forest, arable land, grassland, built-up land, wetland/water body and barren land (Liu, 1996).

In the study area (Liu, 1996), (1) forest means mainly the lands having a tree or shrub-crown area density (crown closure percentage) of 10 percent or more, as well as nurseries and orchards, (2) cropland includes dry-farming cropland and irrigated croplands, lower-cover agroforestry land used mainly for food, and new cultivated river washland in existence for longer than $3 \mathrm{yr}$, (3) grassland is predominantly covered by grasses, grasslike plants, and mixtures of grass and shrubs or trees, but with the coverage of the latter less than $10 \%$, (4) built-up land comprises areas of intensive use covered by structures including cities, towns, villages, strip developments along highways, and transportation, power, and communications facilities, (5) wetland/water body areas include natural wetlands like swamps, lakes, and rivers and water engineering structures like reservoirs and newly built check-dams, (6) barren land refers to land with limited ability to support life, like sand or rocks where vegetation cover is normally less than $5 \%$.

Soil and water conservation data up to 1999 came from Soil and Water Conservation Data Compilation of the Yellow River, compiled by the Upper and Middle Yellow River Bureau in 2010 based on on-site field surveys and measures. The data covers some general conditions of the Yan River basin, as well as biological conservation measures such as man-made forest, grass-planting and hillside closure (natural restoration area with little to no disruption from human activity), and structural measures like terraces, reservoirs, checkdams and key projects for gully control.

\subsection{Methods}

\subsubsection{Trend detection}

Parametric and non-parametric methods have been developed and successfully applied in hydro-climatic field analysis because of their advantage concerning the detection of physical relationships between ecological elements (Galeati, 1990; Iorgulescu and Beven, 2004; Xu et al., 2011). However, they require more detailed data than other methods, which might be difficult to get, as well as clear descriptions of processes, which might not be developed yet (Walling and Fang, 2003). In this study, a linear regression method is used to detect the trends for precipitation, temperature, runoff and sediment load.

\subsubsection{Stage detection}

Mass curves of anomalies were used to analyze and detect the trends and stages as a graph of the cumulative characteristic value on the ordinate (y-axis), plotted against time or date on the abscissa ( $\mathrm{x}$-axis). These mass curves were developed for the parameters annual precipitation (a.pptn), annual mean, maximum and minimum air temperature $\left(t, t_{\max }\right.$ and $t_{\min }$, respectively), runoff $(R)$, sediment load $(S)$ and sediment concentration (SC). The anomalies of the mentioned parameters were transformed into comparable indices by normalized treatment. The value of ordinate $\left(Y_{o, i}\right)$ derives from the equations below:

$Y_{\text {mean }}=\frac{1}{n} \sum_{i=1}^{n} Y_{d i}$
$Y_{a, i}=Y_{d i} / Y_{\text {mean }}-1, i=1,2, \ldots, n$
$Y_{o, 1}=Y_{a, 1}$
$Y_{o, m}=Y_{o, m-1}+Y_{a, m}, m=2,3, \ldots, n$.

Here, $Y_{\text {mean }}, Y_{d i}, Y_{a, i}, Y_{a, m}, Y_{o, 1}$, and $Y_{o, m}$ are the average of the original dataset, original data at year $i$ and anomaly normalized value, accumulating anomaly normalized values at year 1 and $m$, respectively.

The mass curve can show the stages of the whole process and they end at 0 because each $Y_{a, i}$ is an anomaly normalized value. When the curve rises or declines, the original data in this stage is more or less than the average of the whole period, respectively. We treated a continuous change lasting more than $3 \mathrm{yr}$ as the same stage in this paper to reduce the number of stages with very short duration.

\subsubsection{Similar weather condition analysis}

Because the LUC data are only available from 1980 and do not cover all years, and because precipitation is the main source of runoff and the main driving force of erosion, paired periods with similar precipitation and temperature conditions (SPTC) were selected to make the analysis easier (Wang et al., 2008). The differences of precipitation and temperature between paired periods with SPTC should be small enough according to the requirement and objectives of research. The following rules were applied to define paired periods here: (1) the two years have annual precipitation (in $\mathrm{mm}$ ) that differs by less than $1 \%$; (2) the two years have average temperatures (in ${ }^{\circ} \mathrm{C}$ ) that differ by less than $1 \%$; (3) the two years were more than $5 \mathrm{yr}$ apart. Because the natural landform and vegetation evolution is quite slow, runoff and sediment load changes in a SPTC pair are mainly induced by human activities. Using the rules explained above, 12 sets of paired years were defined. It is important to emphasize that this method 
assumes that weather conditions were similar based on just the yearly averages and totals. This is a significant assumption for the study area, because it is well known that individual rainfall events can contribute about $60 \%$ to $90 \%$ of yearly rainfall totals (Li et al., 2010). However, such an effect from individual events would cause scatter in the differences between different years. Therefore if systematic differences are found with our approach it indicates that, apart from rainfall and temperature, other factors are of importance.

\subsubsection{LUC change analysis}

The areas of each category of the five maps are abstracted by GIS to show the land use change process of several sections. A LUC change matrix was used to illustrate the changes of land use and cover for the period 1980 to 2005 based on the LUC maps.

\section{Results and discussion}

\subsection{Statistics}

\section{Runoff and sediment load}

The statistics for runoff, sediment load and the main weather factors that impact them are shown in Table 1. The mean annual runoff, sediment concentration and sediment load were $203.5 \mathrm{M} \mathrm{m}^{3}, 177.7 \mathrm{~kg} \mathrm{~m}^{-3}$ and $41.5 \mathrm{Mt}$, respectively. The difference between maximum and minimum values of each item was large. The runoff in 1964 was 4.74 times of that in 2008; the sediment concentration in 1966 was 31.14 times of that in 2008 and the sediment load in 1954 was 140 times that of 2008. The coefficients of variation (CVs) of runoff, sediment concentration and sediment load are 0.366 , 0.523 and 0.851 , respectively, meaning that the runoff and sediment changes are highly unstable.

\subsection{Meteorological factors}

The main weather variables that impact runoff and sediment load are precipitation and temperature. Precipitation is the only water source for runoff and soil moisture, and is also the driving force for soil erosion and sediment delivery in this region. In the Yan River basin, precipitation varies greatly between seasons and between different years. The mean annual and rainy season precipitation were $504.7 \mathrm{~mm}$ and $436.3 \mathrm{~mm}$, respectively (Table 1), and the rainy season precipitation accounts on average for $86.44 \%$ of annual precipitation. The maximum records of a.pptn $(853.7 \mathrm{~mm})$ and r.pptn $(737.6 \mathrm{~mm})$ in 1964 are 3.28 and 3.78 times the minimum a.pptn $(259.9 \mathrm{~mm})$ and r.pptn $(195.0 \mathrm{~mm})$ in 1997, and the CV values for a.pptn and r.pptn are 0.239 and 0.268 , respectively. The temperature had a mean value of $9.9^{\circ} \mathrm{C}$, a difference of $3.1^{\circ} \mathrm{C}$ between the maximum of $11.5^{\circ} \mathrm{C}$ in 1998 and the minimum of $8.4^{\circ} \mathrm{C}$ in 1967 and a very small $\mathrm{CV}$
(0.083). The precipitation and temperature were more stable than runoff, sediment concentration and sediment load.

\subsection{Trends}

\subsubsection{Runoff and sediment load}

The annual runoff, sediment concentration and sediment load all have significant trends of linear decline in the last $60 \mathrm{yr}$ (Fig. 2), and the average declining rate of annual runoff, sediment load and sediment concentration were $1.32 \mathrm{M} \mathrm{m}^{3} \mathrm{yr}^{-1}$, $0.71 \mathrm{Mt} \mathrm{yr}^{-1}$ and $2.34 \mathrm{~kg} \mathrm{~m}^{-3} \mathrm{yr}^{-1}$, respectively.

\subsubsection{Precipitation and temperature change}

The annual precipitation declined during the period of study, but the trend was not significant $(P>0.1)$ (Fig. 3). The annual mean, maximum and minimum temperatures $\left(t, t_{\max }\right.$ and $t_{\min }$, respectively) all increased significantly during the research period. The changing rates of $t, t_{\max }$ and $t_{\min }$ were $0.038^{\circ} \mathrm{C} \mathrm{yr}^{-1}, 0.019^{\circ} \mathrm{C} \mathrm{yr}^{-1}$ and $0.046^{\circ} \mathrm{C} \mathrm{yr}^{-1}$, respectively. The increasing average temperature is more the result of higher minimum temperatures than from higher maximum temperatures.

\subsection{Stages}

The mass curve of anomaly values describes the change process of a particular parameter by comparing it with the mean value of that parameter over the whole study period. If the observed data from given year is bigger than the overall mean, the anomaly values will be positive and the mass curve will rise. The mass curve of anomaly values show the change from another aspect, e.g. the temperature increasing in a time-value plot could be shown as a line (Fig. 3), but it is a U-shaped curve in a time-mass plot (Fig. 4).

Over the whole study period, the mass curves of $t, t_{\max }$ and $t_{\min }$ showed similar changes by declining first and then rising; the changing points of $t$ and $t_{\min }$ were at 1988 and $t_{\max }$ in 1996. This indicates that mean annual $t$ and $t_{\min }$ before 1988 were smaller than the mean for the whole period, but that after 1988 they were higher than the mean of the whole period. The mass curve of a.pptn was complex with many short-time up- and down phases.

The river characteristics displayed similar changes, but were much more complex than temperature and precipitation (Fig. 4). According to the rules that were applied to detect stages from the mass curves of anomalies of normalized runoff, sediment load and sediment concentration, 4 stages were determined. The first from 1951 to 1971 (1970 for runoff, Stage I), followed by 1972 to 1986 (Stage II), 1987 to 1996 (Stage III) and 1997 to 2010 (Stage IV) (Fig. 2). The abrupt increase in 1977 was put in Stage II according to the rule of stage detection as a single year. The mean value for runoff, sediment load and sediment concentration in each of 
Table 1. Statistics for runoff $(R)$, sediment concentration (SC), sediment load $(S)$, precipitation (pptn), and temperature $\left(t, t_{\mathrm{max}}\right.$ and $\left.t_{\mathrm{min}}\right)$ of the Yan River in 1952-2010.

\begin{tabular}{lrrrrrrrr}
\hline Statistic value & $\begin{array}{r}R \\
\mathrm{M} \mathrm{m}^{3}\end{array}$ & $\begin{array}{r}S \\
\mathrm{Mt}\end{array}$ & $\begin{array}{r}\mathrm{SC} \\
\mathrm{kg} \mathrm{m}^{-3}\end{array}$ & $\begin{array}{r}\text { a.pptn } \\
\mathrm{mm}\end{array}$ & $\begin{array}{r}\text { r.pptn } \\
\mathrm{mm}\end{array}$ & $\begin{array}{r}t \\
{ }^{\circ} \mathrm{C}\end{array}$ & $\begin{array}{r}t_{\max } \\
{ }^{\circ} \mathrm{C}\end{array}$ & $\begin{array}{r}t_{\min } \\
{ }^{\circ} \mathrm{C}\end{array}$ \\
\hline Mean & 203.5 & 41.5 & 177.7 & 504.7 & 436.3 & 9.9 & 17.4 & 4.2 \\
Minimum & 106.0 & 1.3 & 12.3 & 259.9 & 195.0 & 8.4 & 15.6 & 2.2 \\
(Year) & $(2008)$ & $(2008)$ & $(2008)$ & $(1997)$ & $(1997)$ & $(1967)$ & $(1954)$ & $(1952)$ \\
Maximum & 502.1 & 182.0 & 383.0 & 853.7 & 737.6 & 11.5 & 19 & 5.9 \\
(Year) & $(1964)$ & $(1964)$ & $(1966)$ & $(1964)$ & $(1964)$ & $(1998)$ & $(1999)$ & $(2006)$ \\
Standard deviation & 74.47 & 35.23 & 93.00 & 120.65 & 116.94 & 0.82 & 0.84 & 0.93 \\
Confidence levels (95.0\%) & 19.41 & 9.18 & 24.24 & 31.44 & 30.47 & 0.21 & 0.22 & 0.24 \\
CV & 0.366 & 0.851 & 0.523 & 0.239 & 0.268 & 0.083 & 0.048 & 0.222 \\
\hline
\end{tabular}

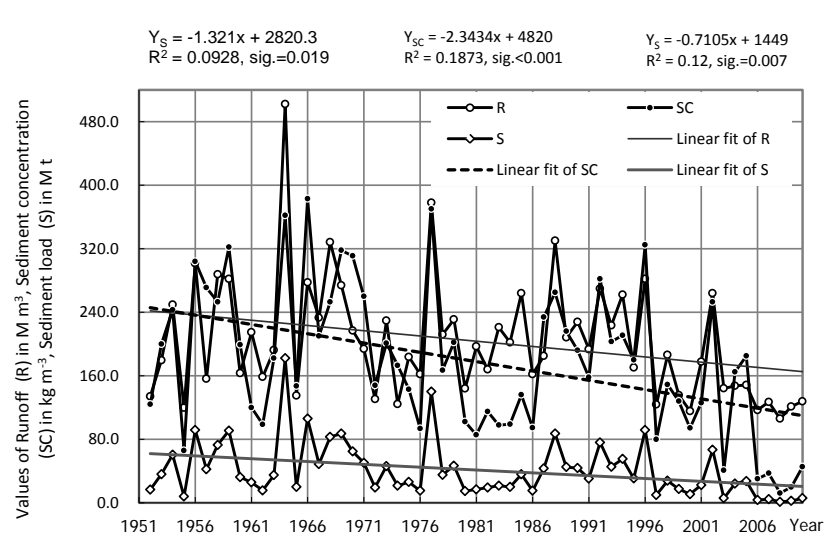

Fig. 2. Annual runoff, sediment concentration and sediment load change in 1952-2010.

these stages was calculated from the raw data and are shown in Table 2.

In stage I, the mean a.pptn was $524.9 \mathrm{~mm}$, more than the mean value for the whole process $(504.7 \mathrm{~mm})$, but the mean annual temperature was $9.20^{\circ} \mathrm{C}$ (cooler than the whole period) (Tables 1 and 2). Mean $R, \mathrm{SC}$ and $S$ were $230.0 \mathrm{M} \mathrm{m}^{3}$, $231.3 \mathrm{~kg} \mathrm{~m}^{-3}$ and $58.5 \mathrm{Mt}$, respectively, all more than the mean values for the whole period. The characteristics in Stage III were similar to those of Stage I, but the mean temperature $\left(10.0^{\circ} \mathrm{C}\right)$ was higher than Stage I and the mean for the whole period. All the mean characteristics in Stage II were less than those for the whole period, except for precipitation which was nearly the same as the whole period mean. The mean a.pptn in Stage IV was $464.0 \mathrm{~mm}$, about $8 \%$ less than that for the whole period, and the mean temperature was $1.2^{\circ} \mathrm{C}$ higher than the whole period. Mean $R, \mathrm{SC}$ and $S$ were $145.9 \mathrm{M} \mathrm{m}^{3}, 97.6 \mathrm{~kg} \mathrm{~m}^{-3}$ and $16.5 \mathrm{Mt}$, respectively, all less than the mean values for the whole period, the decreases being $28.3 \%, 45.1 \%$ and $60.2 \%$, respectively.

For runoff, sediment load and sediment concentration, the differences between the different stages were very different. The mean annual runoff in Stage IV was $145.9 \mathrm{Mm}^{3}$, just

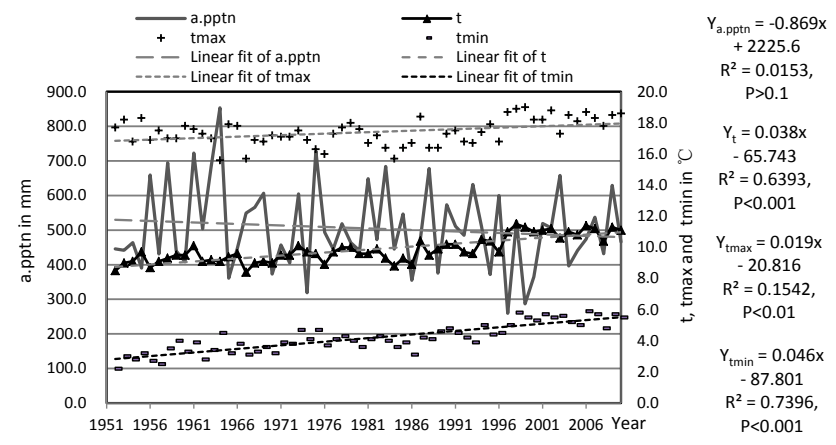

Fig. 3. Annual precipitation and temperature change in 1952-2010.

$63.4 \%$ of that in Stage I. The sediment load in Stage I was 58.48 Mt, about 3.5 times of that in Stage IV. The mean sediment concentrations in Stage I and III were $231.3 \mathrm{~kg} \mathrm{~m}^{-3}$ and $226.6 \mathrm{~kg} \mathrm{~m}^{-3}$, and in Stage II and IV $148.5 \mathrm{~kg} \mathrm{~m}^{-3}$ and $97.6 \mathrm{~kg} \mathrm{~m}^{-3}$, respectively. The reduction from Stage I to Stage IV was $133.7 \mathrm{~kg} \mathrm{~m}^{-3}$ between Stage IV and I (about $58 \%$ ).

In Stage I and III, the mass curves are on the whole positive, meaning that the annual values are usually more than the mean annual value for the whole period. The differences in the mean annual value of each parameter are quite small (2.28\% for runoff, $2.04 \%$ for sediment concentration and $6.11 \%$ for sediment load). The mean annual values in Stage II and IV are less than their long-term mean annual values.

In the 4 stages (Table 2), the mean annual precipitations of Stages I, II and III are very similar, with the differences being less than $21 \mathrm{~mm}$ (about $5 \%$ ). However mean annual precipitation in Stage IV was $57.48 \mathrm{~mm}$ less than Stage III (about $11 \%$ ). Meanwhile, the temperature increased in each stage from 9.02 , to $9.52,10.01$ and $11.06^{\circ} \mathrm{C}$. This is similar to the increasing temperature trend for the whole Yellow River basin (The Ministry of Water Resources and Ministry of Environmental Protection of China, 2010), but is very different from the trends for the whole of China (Piao et al., 2010), which, for the period 1960-2006, showed strong 
Table 2. Mean characteristics of each stage as identified by mass curve anomalies of normalized runoff $(R)$, sediment load $(S)$ and sediment concentration (SC).

\begin{tabular}{llrrrrr}
\hline Stage & & $\begin{array}{r}R \\
\mathrm{M} \mathrm{m}^{3}\end{array}$ & $\begin{array}{r}S \\
\mathrm{Mt}\end{array}$ & $\begin{array}{r}\mathrm{SC} \\
\mathrm{kg} \mathrm{m}^{-3}\end{array}$ & $\begin{array}{r}\text { a.pptn } \\
\mathrm{mm}\end{array}$ & $\begin{array}{r}t \\
{ }^{\circ} \mathrm{C}\end{array}$ \\
\hline I (1952-1971) & & 230.0 & 58.5 & 231.3 & 524.9 & 9.2 \\
II (1972-1986) & & 200.6 & 32.9 & 148.5 & 504.7 & 9.5 \\
Difference (II - I) & Value & -29.4 & -25.6 & -82.8 & -20.2 & 0.3 \\
& $\%$ & -12.8 & -43.7 & -35.8 & -3.8 & 3.6 \\
III (1987-1996) & & 235.3 & 54.9 & 226.6 & 521.4 & 10.0 \\
Difference (III - II) & Value & 34.6 & 22.0 & 78.1 & 16.7 & 0.5 \\
& $\%$ & 17.3 & 66.7 & 52.6 & 3.3 & 5.1 \\
IV (1997-2010) & & 145.9 & 16.5 & 97.6 & 464.0 & 11.1 \\
Difference (IV - III) & Value & -89.4 & -38.4 & -129.0 & -57.5 & 1.1 \\
& $\%$ & -38.0 & -70.0 & -56.9 & -11.0 & 10.5 \\
Difference (IV - I) & Value & -84.2 & -42.0 & -133.8 & -60.9 & 1.9 \\
& $\%$ & -36.6 & -71.9 & -57.8 & -11.6 & 20.3 \\
\hline
\end{tabular}

differences between northeastern (decrease), northwestern (increase) and southeastern China (increase).

Changes in runoff, sediment load and sediment concentration in each stage were found to be much greater than changes in precipitation. Trying to account for this through consideration of only the differences in precipitation and temperature between the different stages is difficult, e.g. how an increase of just $3.3 \%$ in precipitation and $5.1 \%$ in temperature could induce an increase of $17.3 \%$ for runoff and $66.7 \%$ for sediment load (Stage III compared to Stage II). These data, therefore, suggest that factors other than climatic ones might also be of importance. Thus, the impacts of factors like LUC change and constructions in the basin should also be considered and analyzed.

\subsection{Relationship between river and meteorological factors}

The relationships between river and climate factors are shown in Table 3. Runoff and sediment load and annual and rainy season precipitation are all very significant. However sediment concentration, which is a meaningful indicator for river quality because it determines the transportation and siltation of sediment in the river channel and reservoirs downstream (Terrio, 2008; Van Maren et al., 2009; Ma et al., 2012), has no good relationships with pptn. This suggests that this parameter is likely more affected by factors other than precipitation, like temperature and human activity. $R, \mathrm{SC}$ and $S$ all have a significant negative relationship with temperature. This is perhaps because the higher temperatures can induce increased evaporation and reduced runoff and sediment generation. Due to the strong correlation between sediment load and sediment concentration, sediment concentration would also be reduced. The relationships between precipitation and runoff or sediment load are usually non-linear because of all the processes that operate between precipitation and runoff generation, such as interception by vegetation and litter on the soil surface (Helvey and Patric,

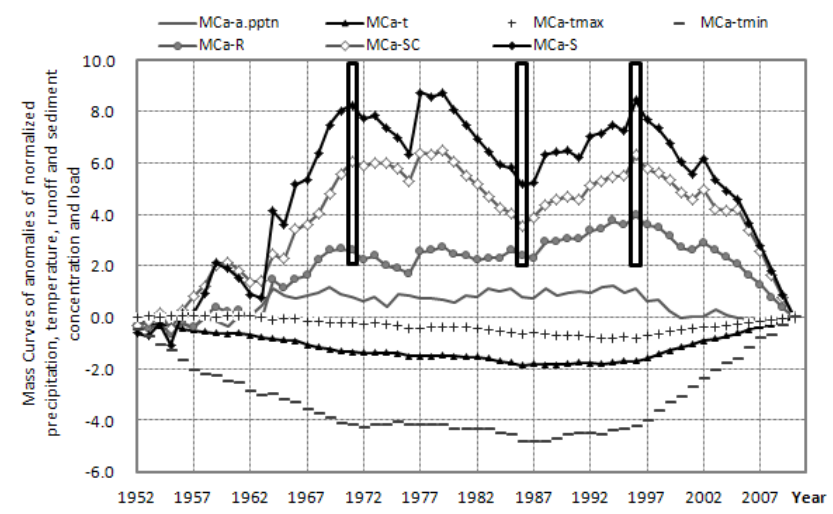

Fig. 4. Mass curves of anomalies of normalized characteristics of GHS in 1952-2010. (The boxes in the figure are the change points)

1965; Huang et al., 2005), as well as infiltration and evaporation which are affected by multiple factors like weather, landform and soil and vegetation conditions. A comparison of runoff and sediment load between paired years with similar precipitation and temperature conditions (SPTC) allows for a better study of the changes because the same premise is set with just one additional assumption, that the evolution of natural landform and vegetation is slow enough to neglect over intervals of several decades.

\subsection{Runoff and sediment load between paired years with SPTC}

The changes in runoff and sediment load when investigated through SPTC analysis are shown in Table 4. A positive difference for $R, \mathrm{SC}$ and $S$ means the value of the later year is less than that of the earlier year of the two paired years. Such a decrease is considered an improvement in the integrated land surface condition of the basin because the goal of the main management practices in this semi-arid region is to retain more water and sediment on site, or to reduce runoff and sediment load in the river.

The difference of a.pptn and $t$ between paired years in Table 4 is from $0.02-0.97 \%$ and $-0.87 \%-0.56 \%$ of the relative value of paired years, respectively, but the differences in $R, \mathrm{SC}$ and $S$ are very different. When comparing the later year with the earlier year in each set of paired years, there are 6 sets $(4,5,6,8,10$ and 12$)$ of 12 paired years that showed that $R, \mathrm{SC}$ and $S$ reduced (directions negative for all three parameters), and 3 sets (2, 3 and 11) with $R$, SC and $S$ all increasing (positive direction), 2 sets (7 and 9) with a increasing direction in $R$ and decreasing direction in SC and $S$, and 1 set (1) with SC having negative direction but both $R$ and $S$ having positive direction.

Since precipitation and temperature were very similar for the paired years, the effects on $R, S$ and SC can be attributed primarily to human activity. From the data it appears that in the middle and later years of the 1980s, human activity had 
Table 3. Linear related coefficients between precipitation (pptn), runoff $(R)$, sediment concentration (SC) and sediment load ( $S$ ) of Yan River in $1952-2010$.

\begin{tabular}{llllllll}
\hline & a.pptn & r.pptn & $t$ & $t_{\max }$ & $t_{\min }$ & $R$ & $\mathrm{SC}$ \\
\hline a.pptn & 1 & & & & & & \\
r.pptn & $0.974^{* * *}$ & 1 & & & & & \\
$t$ & -0.182 & -0.151 & 1 & & & & \\
$t_{\max }$ & $-0.436^{* * *}$ & $-0.406^{* *}$ & $0.762^{* * *}$ & 1 & & & \\
$t_{\min }$ & 0.030 & 0.046 & $0.911^{* * *}$ & $0.471^{* * *}$ & 1 & & \\
$R$ & $0.537^{* * *}$ & $0.542^{* * *}$ & $-0.377^{* *}$ & $-0.515^{* * *}$ & -0.181 & 1 & \\
$\mathrm{SC}$ & 0.154 & 0.162 & $-0.399^{* *}$ & $-0.316^{*}$ & $-0.336^{* *}$ & $0.779^{* * *}$ & 1 \\
$S$ & $0.359^{* *}$ & $0.358^{* *}$ & $-0.356^{* *}$ & $-0.395^{* *}$ & -0.210 & $0.938^{* * *}$ & $0.904^{* * *}$ \\
\hline
\end{tabular}

Note: When $n=59$, the correlation coefficient of significance at $0.001^{* * *}, 0.01^{* *}$ and $0.1^{*}$ is $0.418,0.333$ and 0.216 , respectively.

The unit of original data: a.pptn and r.pptn in $\mathrm{mm} ; t, t_{\max }$ and $t_{\min }$ in ${ }^{\circ} \mathrm{C} ; R$ in $\mathrm{M} \mathrm{m}^{3} ; \mathrm{SC}$ in $\mathrm{kg} \mathrm{m}^{-3}$ and $S$ in Mt.

Table 4. Changes of runoff $(R)$, sediment concentration (SC) and sediment load $(S)$ within paired similar precipitation years.

\begin{tabular}{|c|c|c|c|c|c|c|c|c|c|c|c|c|c|c|c|c|c|}
\hline \multirow[b]{2}{*}{ No. } & \multicolumn{4}{|c|}{ Year 1 of paired years } & \multicolumn{4}{|c|}{ Year 2 of paired years } & \multicolumn{9}{|c|}{ Difference $^{a}$} \\
\hline & Year & $\begin{array}{r}R \\
\mathrm{M} \mathrm{m}^{3}\end{array}$ & $\begin{array}{r}\mathrm{SC} \\
\mathrm{kg} \mathrm{m}^{-3}\end{array}$ & $\begin{array}{r}S \\
\mathrm{Mt}\end{array}$ & Year & $\begin{array}{r}\mathrm{R} \\
\mathrm{M} \mathrm{m}^{3}\end{array}$ & $\begin{array}{r}\mathrm{SC} \\
\mathrm{kg} \mathrm{m}^{-3}\end{array}$ & $\begin{array}{l}\text { S } \\
\text { Mt }\end{array}$ & Year & $\begin{array}{r}\text { a.pptn } \\
\%\end{array}$ & $\begin{array}{r}t \\
\%\end{array}$ & $\begin{array}{c}R \\
\mathrm{M} \mathrm{m}^{3}\end{array}$ & $\begin{array}{r}\text { SC } \\
\text { Dir\# }\end{array}$ & $\begin{array}{r}S \\
\mathrm{~kg} \mathrm{~m}^{-3}\end{array}$ & Direction & Mt & Dir \\
\hline 1 & 1952 & 133.9 & 124.0 & 16.6 & 1984 & 202.0 & 99.1 & 20.0 & -32 & 0.02 & -0.87 & -68.1 & 2.13 & 24.9 & -0.78 & -3.4 & 0.11 \\
\hline 2 & 1955 & 119.7 & 65.8 & 7.9 & 1989 & 208.3 & 216.0 & 45.0 & -34 & 0.97 & -0.51 & -88.6 & 2.61 & -150.2 & 4.42 & -37.1 & 1.09 \\
\hline 3 & 1963 & 192.3 & 182.0 & 34.9 & 1988 & 330.0 & 265.0 & 87.3 & -25 & 0.21 & -0.80 & -137.7 & 5.51 & -83.0 & 3.32 & -52.4 & 2.1 \\
\hline 4 & 1958 & 287.8 & 253.0 & 72.9 & 1983 & 221.0 & 97.9 & 21.6 & -25 & 0.38 & 0.00 & 66.8 & -2.67 & 155.1 & -6.2 & 51.3 & -2.05 \\
\hline 5 & 1959 & 282.0 & 322.0 & 91.0 & 1980 & 144.0 & 102.0 & 14.7 & -21 & -0.05 & -0.26 & 138 & -6.57 & 220.0 & -10.48 & 76.3 & -3.63 \\
\hline 6 & 1960 & 163.4 & 199.0 & 32.4 & 1972 & 130.7 & 148.0 & 19.3 & -12 & 0.20 & 0.00 & 32.7 & -2.73 & 51.0 & -4.25 & 13.1 & -1.09 \\
\hline 7 & 1962 & 158.6 & 98.8 & 15.7 & 1976 & 162.1 & 93.6 & 15.2 & -14 & 0.52 & 0.56 & -3.5 & 0.25 & 5.2 & -0.37 & 0.5 & -0.04 \\
\hline 8 & 1966 & 277.6 & 383.0 & 106.0 & 1971 & 193.9 & 260.0 & 50.4 & -5 & -0.058 & 0.26 & 83.7 & -16.74 & 123.0 & -24.6 & 55.6 & -11.12 \\
\hline 9 & 1963 & 192.3 & 182.0 & 34.9 & 1983 & 221.0 & 97.9 & 21.6 & -20 & -0.03 & -0.27 & -28.7 & 1.44 & 84.1 & -4.21 & 13.3 & -0.67 \\
\hline 10 & 1978 & 212.0 & 167.0 & 35.2 & 1991 & 193.4 & 158.0 & 30.6 & -13 & 0.35 & -0.50 & 18.6 & -1.43 & 9.0 & -0.69 & 4.6 & -0.35 \\
\hline 11 & 1981 & 197.0 & 85.6 & 16.9 & 1993 & 223.4 & 203.0 & 45.4 & -12 & 0.63 & 0.00 & -26.4 & 2.2 & -117.4 & 9.78 & -28.5 & 2.38 \\
\hline 12 & 1998 & 186.4 & 149.0 & 27.8 & 2007 & 127.0 & 37.2 & 4.7 & -9 & -0.54 & 0.66 & 59.4 & -6.6 & 111.8 & -12.42 & 23.1 & -2.57 \\
\hline
\end{tabular}

Note: ${ }^{a}$ Difference is the time and characteristics value of Year 1 minus that of Year 2. ${ }^{b}$ Dir (Direction) is just to show the changing direction of a certain set of paired years (increase or decrease). It was the ratio of difference of $R$ (SC or $S$ ) divided by the difference of year, and shows the synchronicity of the characteristics and time. A negative value means the value decreased over the years which are desirable, and a positive value means the value increased over the years which are undesirable. The unit of original data: a.pptn in $\mathrm{mm} ; t$ in ${ }^{\circ} \mathrm{C}$.

more negative impacts on soil and water loss than in the early 1950s and 1960s (set 1, 2 and 3). On the other hand, the impact of human activities in the 1970s and early 1980s appear to have been positive when compared with the 1960s (set 49). The human impacts in 1991 and 2007 were positive when compared with 1978 and 1998, respectively, but more negative in 1993 compared to 1981.

\subsection{LUC Change}

Figure 5 provides a visual representation of the LUC for 4 counties in the area upstream of GHS in 1980 and 2010, and Fig. 6 provides details of the LUC for the same period. Forest, arable land and grassland are the main land use categories, accounting for more than $99.20 \%$ of the whole area. Over the period studied, the area covered by forest increased continuously from 44.91 thousand ha in 1980 to 63.50 thousand ha in 2005 , a conversion of $3.13 \%$ of the whole region to forest in $25 \mathrm{yr}$. The area used as arable land declined from 270.78 thousand ha in 1980 to 254.29 thousand ha in 2005 , but not continuously, as it increased by 2.17 thousand ha from 1985 to 1996 . The grassland area decreased from
274.82 thousand ha in 1980 to 272.38 thousand ha in 2005 , almost all of which occurred from 1996 to 2000. The builtup land area nearly doubled because of the intensive houses and infrastructure development, but is still less than 2 thousand ha. More than half of the area converted to built-up area was converted from arable land. The actual area change in area of wetland and water body (Fig. 6) was less than 500 ha in the study period, but this is a decrease of $28 \%$ due to new arable land formation in the upper stream of reservoirs and because of check-dam building across the gullies. The area of barren land remained stable at 250 ha.

Because of the very dissected landform in this region, all categories of land are distributed as small fragmentized pieces (Fig. 5). The arable land along the Yan River and its branches had no clear change, but in the higher area, mainly the west and north parts of Zhidan County, Jingbian county and Ansai county, arable land use decreased, and patches of forest and grassland in that region expanded and even joined together (indicated by a dark purple color in the map for 2005). 

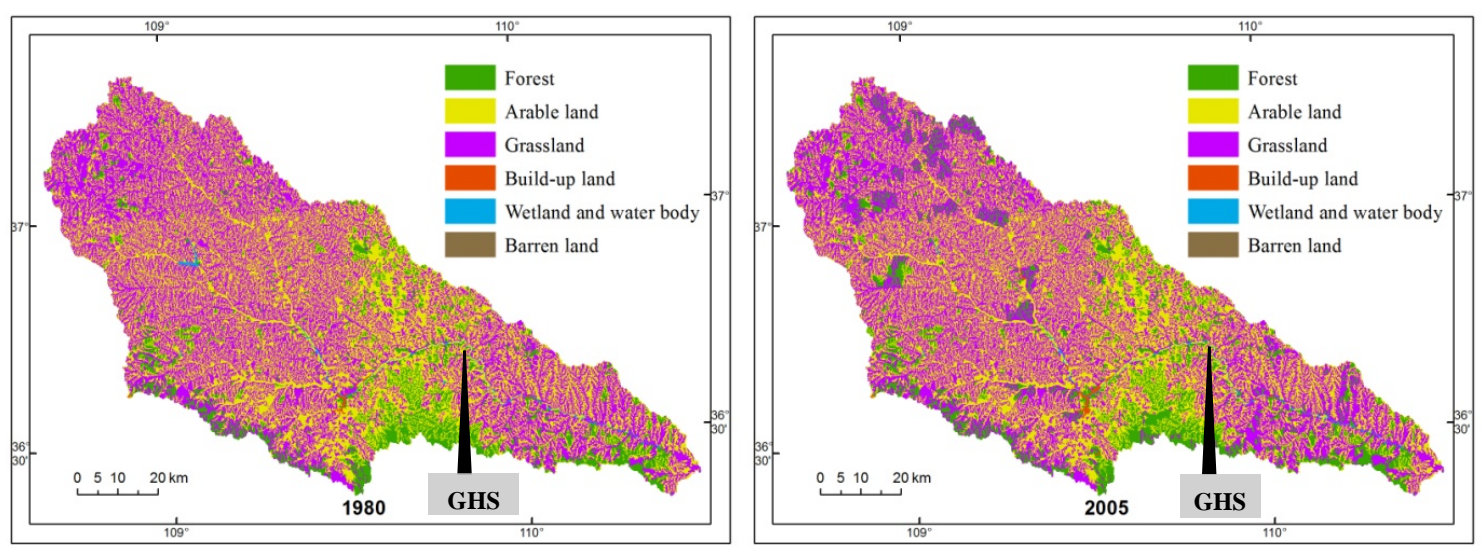

Fig. 5. LUC of the Yan River basin from 1980 and 2005.

Table 5. LUC change matrix of upstream area of GHS from 1980 to 2005 (in ha).

\begin{tabular}{|c|c|c|c|c|c|c|c|c|}
\hline \multirow[b]{2}{*}{ Year } & \multirow[b]{2}{*}{ LUC } & \multicolumn{6}{|c|}{$2005(j)$} & \multirow[b]{2}{*}{$\begin{array}{r}1980 \\
\text { Amount }\end{array}$} \\
\hline & & 1 Forest & $\begin{array}{r}2 \text { Arable } \\
\text { land }\end{array}$ & 3 Grassland & $\begin{array}{r}4 \text { Built-up } \\
\text { land }\end{array}$ & $\begin{array}{l}5 \text { Wetland and } \\
\text { water body }\end{array}$ & $\begin{array}{r}6 \text { Barren } \\
\text { land }\end{array}$ & \\
\hline \multirow[t]{6}{*}{$1980(i)$} & 1 Forest & 44897.17 & - & 1.28 & 12.89 & - & - & 44911.34 \\
\hline & 2 Arable land & 14496.59 & 253045.70 & 2714.55 & 474.47 & 45.88 & - & 270777.18 \\
\hline & 3 Grassland & 4104.85 & 764.26 & 269664.58 & 287.10 & - & - & 274820.79 \\
\hline & 4 Built-up land & - & - & - & 800.67 & - & - & 800.67 \\
\hline & 5 Wetland and water body & - & 481.40 & - & 20.04 & 1091.28 & - & 1592.71 \\
\hline & 6 Barren land & - & - & - & - & - & 251.85 & 251.85 \\
\hline 2005 & Amount & 63498.61 & 254291.35 & $272,380.42$ & 1595.16 & 1137.16 & 251.85 & 593154.55 \\
\hline
\end{tabular}

Note: The value $V_{i, j}$ is the value at the cross of row $i$ of 1980 and column $j$ of 2005. The elements $i$ and $j$ denote: $1=$ Forest; $2=$ Arable land; $3=$ Grassland; $4=$ Built-up land; $5=$ Wetland and water body; $6=$ Barren land. $V_{i, j}$ means the area with no change in category if $i=j$, and area of category $i$ in 1980 changed into category $j$ in 2005 if $i \neq j$; e.g. there were about 270.8 thousand ha and 254.3 thousand ha arable land in 1980 and 2005 , respectively and about 253 thousand ha of land was always arable land without any change $\left(V_{2,2}\right)$, but there were about $14.5,2.7,0.5$ thousand ha of arable land in 1980 converted into forest, grassland and built-up land, respectively $\left(V_{2,1}, V_{2,3}\right.$ and $\left.V_{2,4}\right)$, and meanwhile about 764 ha of grassland and 481 ha of wetland and water body changed into arable land $\left(V_{3,2}\right.$ and $\left.V_{5.2}\right)$.

A matrix based on the LUC change for three counties was developed to show the transfer between different kinds of land use categories in 1980 and 2005 (Table 5). This shows that 1.28 ha and 12.89 ha of forest changed into grassland and built-up land, and 14497 ha of arable land and 4105 ha of grassland changed into forest. In the same period, $2715 \mathrm{ha}$, 474 ha and 46 ha of arable land changed into grassland and wetland and water body, respectively. The increase in builtup land was fast between 1980 and 2005.

\subsection{Soil and water conservation engineering}

In addition to climate variation/changes and land use change, which were presented in the previous sections, engineering is also likely to have influenced runoff, sediment load and sediment concentration of the Yan River. This section discusses the available data on the impact of soil and water conservation engineering, and in Sect. 3.8 an attempt is made to integrate the evidence presented for the effects of changes in climate, changes in land use, and the effect of conservation engineering.
According to Soil and Water Conservation Data Compilation of the Yellow River Basin (Table 6), there are 2 reservoirs in the upstream area of GHS with a total controlled area of $896.4 \mathrm{~km}^{2}$. The siltation amount measured in these reservoirs was $105 \mathrm{M} \mathrm{m}^{3}, 96 \mathrm{M} \mathrm{m}^{3}$ of which was silted in the Wangyao Reservoir (in Ansai County), built in 1970 with an upstream area of $820 \mathrm{~km}^{2}$. There was also $18.8 \mathrm{M} \mathrm{m}^{3}$ of sediment accumulated in the 43 key projects for gully control built since the $1980 \mathrm{~s}$, and $1555 \mathrm{M} \mathrm{m}^{3}$ of sedimentation behind check dams.

Using a dry bulk density of $1.35 \mathrm{t} \mathrm{m}^{-3}$ for the sediment (Ran et al., 2004), this amounts to $2265 \mathrm{Mt}$ of sediment that was silted in this region and therefore did not enter the Yan River, or $56.62 \mathrm{Mt}$ per year when considering the $40 \mathrm{yr}$ period between the start of implementation and 1999. This is a much greater value than the mean value of $41.50 \mathrm{Mt}$ per year that is transported from the Yan River basin as sediment load (Table 1) and is even as high as or higher than the values found for stages I (58.48 Mt mean) and III (54.91 Mt mean) (Table 3). In fact the amount per year is much greater because most of the measures were constructed less than $40 \mathrm{yr}$ ago. 
Table 6. Engineering measures of upstream area of GHS before 1999 (in ha).

\begin{tabular}{|c|c|c|c|c|c|c|}
\hline Type & Character & Unit & Ansai County & Baota District & Zhidan County & Amount \\
\hline \multirow[t]{4}{*}{ Reservoir } & Number & Set & 1 & 1 & - & 2 \\
\hline & Control Area & $\mathrm{km}^{2}$ & 820.0 & 76.4 & - & 896.4 \\
\hline & Capacity & $\mathrm{Mm}^{3}$ & 203.0 & 14.8 & - & 217.8 \\
\hline & Siltation & $\begin{array}{l}\mathrm{Mm}^{3} \\
\mathrm{Mt}\end{array}$ & $\begin{array}{r}96.0 \\
129.5\end{array}$ & $\begin{array}{r}8.5 \\
11.5\end{array}$ & $\begin{array}{l}- \\
-\end{array}$ & $\begin{array}{l}104.5 \\
141.0\end{array}$ \\
\hline \multirow[t]{4}{*}{ Key projects for gully control } & Number & Set & 17 & 26 & - & 43 \\
\hline & Control Area & $\mathrm{km}^{2}$ & 1.1 & 1.9 & - & 3.0 \\
\hline & Capacity & $\mathrm{Mm}^{3}$ & 15.0 & 22.9 & - & 38.0 \\
\hline & Siltation & $\begin{array}{l}\mathrm{Mm}^{3} \\
\mathrm{Mt}\end{array}$ & $\begin{array}{l}7.3 \\
9.9\end{array}$ & $\begin{array}{l}11.5 \\
15.5\end{array}$ & - & $\begin{array}{l}18.8 \\
25.4\end{array}$ \\
\hline \multirow[t]{2}{*}{ Check dam } & Number & Set & 688 & 3049 & 149 & 3886 \\
\hline & Siltation & $\begin{array}{l}\mathrm{Mm}^{3} \\
\mathrm{Mt}\end{array}$ & $\begin{array}{l}275.2 \\
371.5\end{array}$ & $\begin{array}{l}1219.5 \\
1646.4\end{array}$ & $\begin{array}{l}59.8 \\
80.7\end{array}$ & $\begin{array}{l}1554.5 \\
2098.6\end{array}$ \\
\hline \multicolumn{2}{|c|}{ Total amount of siltation } & $\mathrm{Mm}^{3}$ & 378.5 & 1239.5 & 59.8 & 1677.8 \\
\hline
\end{tabular}

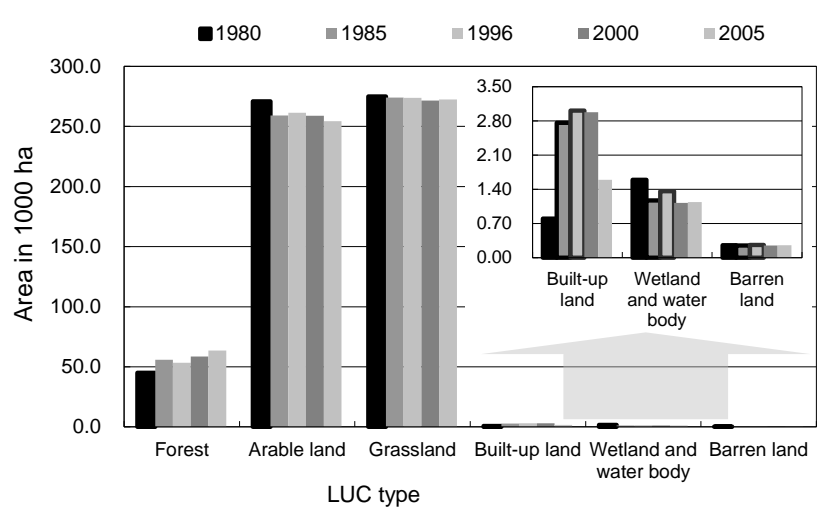

Fig. 6. LUC change in the Yan River basin from 1980 to 2005.

There were $22.45,2.87$ and 3.98 thousand ha of terraces, check-dam land and irrigation cropland by 1999 . Terraces can reduce runoff and soil erosion by $80 \%$ to $100 \%$ compared with sloping cropland (Zhan and Yu, 1994). Checkdam land not only retains sediment from the upstream area and provides a new local base level to reduce incision erosion (Fang et al., 1998), it also has a 4 to 10 times higher, and more stable, yield because of its fertile soil and more available water (Xu et al., 2004). This resulting increased production potential allows local people to reduce cultivation and harvesting on the remote and sloping land that is more prone to runoff and erosion (Wang et al., 2003).

Areas covered by man-made forest and grassland were quite large by 1999 , with $57.53,41.58,24.63$ and 15.51 thousand ha of arbor, shrub, economic trees and grass, respectively (Soil and Water Conservation Data Compilation of the Yellow River Basin). The soil and water control functions of these areas are closely related to coverage of vegetation, and the soil erosion of land with coverage more than $70 \%$ would be well controlled (Jiao et al., 2000). Although in this region cultivation of economic trees, like apple orchards, includes keeping the land between trees bare to avoid moisture loss from evaporation by wild grass, the soil erosion rate could be very high (8000-10 $000 \mathrm{t} \mathrm{km}^{-2} \mathrm{yr}^{-1}$ ) in strong storms even though the canopy coverage is high (Wang and Liu, 2000).

\subsection{Causes for decreased runoff and sediment load}

Earlier sections of this paper presented evidence regarding changes in runoff and sediment load that can be observed from the available data for the Yan River basin. These data showed a relatively small decrease in rainfall, a definite increase in temperature, and very significant decreases in runoff, sediment load and sediment concentration. Data on land use change indicated that the main changes that have occurred in the catchment consisted of an increase in forested area and a decrease in arable land, both of which would influence runoff and erosion. Furthermore, Sect. 3.7 showed that soil and water conservation engineering measures also trapped large amounts of sediments that could otherwise have partly reached the outlet of the Yan River basin.

Thus, it is clear that runoff and sediment load of the Yan River was affected by engineering measures, land use change and climatic change. However, the data that have been used in this paper do not provide proof about the relative importance of each of these factors because all these factors are operating simultaneously and perhaps even partly in dependence on each other. The data do provide some indications, but these can only be quantified if significant assumptions are made, such as for example the assumption made by Miao et 
al. (2011) that human influence in the 1950s could be neglected and that for the 1950s data, a regression equation could therefore be developed that describes how runoff and sediment load would change solely under the influence of climate change. By extrapolating this equation to other decades, they were then able to separate the effect of human action from that of climate. In this study, we did not use such an assumption, but rather looked at indications that are found in the data, such as:

- decreases in runoff, sediment load and sediment concentration are larger than increases in temperature and decreases in rainfall. This, in itself, is not proof that other factors than temperature and rainfall are also at play, as relationships between temperature \& rainfall and runoff $\&$ sediment load are not likely to be linear. However, the relatively low correlation between sediment concentration and precipitation as well as temperature (Table 3) does indicate that sediment concentration is partly controlled by other factors than climate.

- the SPTC analysis of paired similar weather years shows that for years with similar rainfall and temperature, the later chronological year had lower runoff, sediment concentration and sediment load for 6,9 and 8 out of $12 \mathrm{yr}$, respectively. Despite the caution that is needed for this method, because of the large influence of individual events on yearly totals of runoff and sediment load, this also indicates that factors other than climate also play a role.

- the LUC change data show an increase in forested land, and a decrease in arable land, which according to accepted knowledge would result in a decrease of runoff and sediment load at catchment scale.

- data on sedimentation at engineering structures of different scales show that significant amounts of sediment were captured. What the impact of this at catchment scale would be, however, is difficult to say, as the trapped sediment might also have deposited otherwise, while conversely new sediment might have been entrained by the clearer water that flowed out of e.g. the reservoirs.

Hence, there are indications from the comparison of climatic data with runoff and sediment load that suggest that factors besides climate were involved in runoff and sediment changes, and there is also evidence that human activity (structures, land use) has decreased runoff and sediment load. Therefore, it can be expected that further human intervention by way of land management measures would be able to further influence runoff, sediment load and sediment concentration of the Yan River and other rivers on the Chinese Loess Plateau.

\section{Summary and conclusions}

Global climate change has undoubtedly already influenced ecosystems and their functions and processes. In addition, human activity has also undoubtedly influenced ecosystems and processes. It can be very difficult to distinguish the impacts induced by climate change and human activities, yet this information can be of great value for developing management and adaptation strategies. In the Yan River basin, the river runoff and sediment load declined dramatically over the last $60 \mathrm{yr}$. The non-significant decline in precipitation and significant increase in temperature can only partly explain these changes in runoff and sediment load.

The stages of river runoff, sediment load and climate change could be divided according to mass curves of anomalies of observed data, and the mass curves of normalized characteristics could put all change processes in one plot easily for better analysis. Four (4) clear stages of runoff and sediment load change were detected. The runoff and sediment load in Stage III (1987 to 1996) especially did not match the whole change processes, with runoff being $17-38 \%$ higher than in neighboring stages, and sediment load being $66-70 \%$ higher.

The paired-year method can be useful to study the impacts of human activities, as it can be assumed that other factors that cause changes in runoff and sediment load, such as natural landform change, vegetation and soil evaluation are slow processes compared to the activities of human beings. As years with similar weather were selected, observed differences in runoff and sediment would therefore be due to human action.

The human impacts relating to LUC change and soil and water measures in this basin were very important both because of the transfer of sloping cropland into non-food vegetation or cultivable terraces, and because of siltation in reservoirs and behind check dams. Data for the study site show that about $2264.96 \mathrm{Mt}$ in total or $56.62 \mathrm{Mt}$ annual average of sediment were silted in the basin during 1960-1999. This value is larger than the amount of sediment that is, on average, leaving the Yan Basin, which was $41.50 \mathrm{Mt}$ per year in last $60 \mathrm{yr}$. This is one of the clearest indications that human activity had a significant impact on runoff and sediment loss.

Thus, both climate change and human activity are important factors in explaining the observed variation in runoff and sediment load. However, as the effect of both are integrated at catchment scale, accurate determination of exactly which part of the observed changes were due to climate change, and which to human management is extremely difficult if not impossible. Nevertheless, the results of this study clearly indicate that changes in human management of the Yan Basin would be likely to result in changes in runoff and soil loss at the scale of the whole basin. 
Acknowledgements. The research described in this paper was conducted within the framework of the EC-DG RTD, 6th Framework Research Programme (sub-priority 1.1.6.3), Research on Desertification, project DESIRE (037046): Desertification Mitigation and Remediation of Land - a global approach for local solutions. It was also supported by the CNW-JSTP programme 842.00.003 of the Netherlands Organisation for Scientific Research, the National Natural Science Foundation of China (No. 41171420 and No. 41271295), the Key Research Program of the Chinese Academy of Sciences (No. KZZD-EW-04), and Fundamental Research Funds for the Central Universities (No. QN2011150). The authors wish to thank Erik van den Elsen for his comments and Ms. Demie Moore for improving the English of the manuscript.

Edited by: A. D. Reeves

\section{References}

China Meteorological Administration: Specifications for surface meteorological observation. Beijing, China Meteorological Press, 35-44, 60-67, 93-116, 2003 (in Chinese).

Douglas, I.: Land degradation, soil conservation and the sediment load of the Yellow River, China: review and assessment, Land Degrad. Dev., 1, 141-151, doi:10.1002/ldr.3400010206, 1989.

Fang, X., Wang, Z., Kuang, S. Mechanism and effect of check-dam to intersect sediment in the middle reach of Yellow River, J. Hydraul. Eng., 20, 49-53, 1998 (in Chinese)

Feng, X., Wang, Y., Chen, L., Fu, B., and Bai, G.: Modeling soil erosion and its response to land-use change in hilly catchments of the Chinese Loess Plateau, Geomorphology, 118, 239-248, doi:10.1016/j.geomorph.2010.01.004, 2010.

$\mathrm{Fu}, \mathrm{B}$. and Gulinck, H.: Land evaluation in an area of severe erosion: The Loess Plateau of China, Land Degrad. Dev., 5, 33-40, doi:10.1002/ldr.3400050105, 1994.

Galeati, G.: A comparison of parametric and non-parametric methods for runoff forecasting, Hydrolog. Sci. J., 35, 79-94, doi:10.1080/02626669009492406, 1990.

Helvey, J. D. and Patric, J. H.: Canopy and litter interception of rainfall by hardwoods of Eastern United States, Water Resour. Res., 1, 193-206, doi:10.1029/WR001i002p00193, 1965.

Hessel, R., Jetten, V., Messing, I., Chen, L., Stolte, J., and Ritsema, C. J.: Soil erosion simulations of land use scenarios for a small Loess Plateau catchment, Catena, 54, 289-302, doi:10.1016/S0341-8162(03)00070-5, 2003.

Huang, Y., Chen, S., Lin, T.: Continuous monitoring of water loading of trees and canopy rainfall interception using the strain gauge method, J. Hydrol., 311, 1-7, doi:10.1016/j.jhydrol.2004.08.036, 2005.

Iorgulescu, K. and Beven, J.: Nonparametric direct mapping of rainfall-runoff relationships: An alternative approach to data analysis and modeling?, Water Resour. Res., 40, W08403, doi:10.1029/2004WR003094, 2004.

Jiang, D., Qi, L., and Tan, J.: Soil erosion and conservation in the Wuding River Valley, China, in: Soil Conservation: Problems and prospects, edited by: Morgan, R. P. C., Chichester: Wiley, 461479, 1981.

Jiao, J., Wang, W., and Li, J.: Effective cover rate of woodland and grassland for soil and water conservation, Acta Phytoecologica Sinica, 24, 608-612, 2000 (in Chinese).
Li, Z., Liu, W., Zhang, X., and Zheng, F.: Impacts of land use change and climate variability on hydrology in an agricultural catchment on the Loess Plateau of China, J. Hydrol., 377, 35-42, doi:10.1016/j.jhydrol.2009.08.007, 2009.

Li, Z., Zheng, F., and Liu, W.: Analyzing the Spatial temporal Changes of Extreme Precipitation Events in the Loess Plateau from 1961 to 2007, J. Nat. Resour., 25, 291-299, 2010 (in Chinese).

Liu, J.: Macro scale survey and dynamic study of natural resources and environment of China by Remote Sensing. Chinese Scientific Technological Press, Beijing, 1-67, 1996 (in Chinese).

Long, Y. and Xiong, G.: Sediment measurement in the Yellow River, IAHS P., 133, 275-285, 1981.

Ma, Y., Huang, H., Nanson, G. C., Li, Y., and Yao, W.: Channel adjustments in response to the operation of large dams: The upper reach of the lower Yellow River, Geomorphology, 147-148, 35-48, doi:10.1016/j.geomorph.2011.07.032, 2012.

Miao, C., Ni, J., Borthwick, A. G. L., and Yang, L.: A preliminary estimate of human and natural contributions to the changes in water discharge and sediment load in the Yellow River, Global Planet. Change, 76, 196-205, doi:10.1016/j.gloplacha.2011.01.008, 2011.

Ministry of Water Resources of China: China River Sediment Bulletin 2010, China WaterPower Press, Beijing, 2011 (in Chinese).

Peng, J., Chen, S., and Dong, P.: Temporal variation of sediment load in the Yellow River basin, China, and its impacts on the lower reaches and the river delta, Catena, 83, 135-147, doi:10.1016/j.catena.2010.08.006, 2010.

Piao, S., Ciais, P., Huang, Y., Shen, Z., Peng, S., Li, J., Zhou, L., Liu, H., Ma, Y., Ding, Y., Friedlingstein, P., Liu, C., Tan, K., Yu, Y., Zhang, T., and Fang, J.: The impacts of climate change on water resources and agriculture in China, Nature, 467, 43-51, doi:10.1038/nature09364, 2010.

Ran, D., Luo, Q., Liu, B., and Wang, H.: Effect of soil retaining dams on flood and sediment reduction in middle reaches of Yellow River, J. Hydraul. Eng., 25, 7-13, 2004 (in Chinese).

Ren, M. and Zhu, X.: Anthropogenic influences on changes in the sediment load of the Yellow River, China, during the Holocene, Holocene, 4, 314-320, 1994.

State Quality Supervision Bureau and Ministry of Construction of China: Code for measurements of suspended sediment in open channels (GB50159-92). Beijing, Standards Press of China, 638, 1992 (in Chinese).

State Quality Supervision Bureau and Ministry of Construction of China: Code for measurement of liquid flow in open channels (GB50179-93), Beijing, Standards Press of China, 13-40, 1993 (in Chinese).

Terrio, P. J.: Analysis of suspended-sediment concentrations and discharges at four long-term sediment stations in Central and Southern Illinois, 1975-92 Water Years, Water-Resources Investigations Report 96-4204, 1-2, 2008.

The Ministry of Water Resources and Ministry of Environmental Protection of China: Yellow River Climate Change Scenario Development Project, Rapid Assessment, EU China RBMP Research and Study Report R\&S-009, 18-20, 2010.

Van Maren, D. S., Winterwerp, J. C., Wang, Z., and Pu, Q.: Suspended sediment dynamics and morphodynamics in the Yellow River, China, Sedimentology, 56, 785-806, doi:10.1111/j.13653091.2008.00997.x, 2009. 
Walling, D. E. and Fang, D.: Recent trends in the suspended sediment loads of the world's rivers, Global Planet. Change, 39, 111126, doi:10.1016/S0921-8181(03)00020-1, 2003.

Wan, Z. and Wang, Z.: Hyperconcentrated flow, IAHR Monograph, Rotterdam, Balkema, 1994.

Wang, D., Fu, B., Lu, K., Xiao, L., Zhang, Y., and Feng, X.: Multifractal analysis of land use pattern in space and time: A case study in the Loess Plateau of China, Ecol. Complex., 7, 487-493, doi:10.1016/j.ecocom.2009.12.004, 2010.

Wang, F., Li, R., and Wen, Z.: Questions and Proposal on Policy of Converting Cropland into Forest and Grassland - A Case-based Study, Journal of Northwest Sci-tech University of Agriculture and Forestry (Social Sciences) 3, 60-65, 2003 (in Chinese).

Wang, F., Tian, J., Mu, X., Li, R., and Söderlund, L.: Impact of soil and water conservation practices on sediment particle size in Yanhe River, China, Agrifood Research Reports, 68, 95-103, 2005.

Wang, F., Mu, X., Li, R., and Jiao, J.: Change Characteristic of the Runoff and Sediment under the Similar Precipitation Condition in the Beiluohe River, Journal of Water Resources and Water Engineering, 19, 36-40, 2008 (in Chinese).

Wang, H. and Liu, G.: The basic characteristic of effective erosion preventing by plant: Closing ground coverage, Soil and Water Conservation in China, 3, 28-31, 2000 (in Chinese).

Wang, Q., Fan, X., Qin, Z., and Wang, M.: Change trends of temperature and precipitation in the Loess Plateau Region of China, 1961-2010, Global Planet. Change, 92-93, 138-147, doi:10.1016/j.gloplacha.2012.05.010, 2012.
Xu, H., Bin, Z., and Song, Y.: Impacts of climate change on headstream runoff in the Tarim River Basin, Hydrol. Res., 42, 20-29, doi:10.3724/SP.J.1227.2011.00220, 2011.

$\mathrm{Xu}, \mathrm{J}$.: Historical bank-breachings of the lower Yellow River as influenced by drainage basin factors, Catena, 45, 1-17, doi:10.1016/S0341-8162(01)00136-9, 2001.

$\mathrm{Xu}, \mathrm{X}$., Zhang, H., and Zhang, O.: Development of check-dam systems in gullies on the Loess Plateau, China, Environ. Sci. Policy, 7, 79-86, doi:10.1016/j.envsci.2003.12.002, 2004.

Zhan, S. and Yu, Y.: Methods of Calculating effect of Soil and Water Conservation Measures. China Environmental Sciences Press, Beijing, 1994 (in Chinese).

Zhang, J., Huang, W., and Shi, M.: Huanghe (Yellow River) and its estuary: sediment origin, transport and deposition, J. Hydrol., 120, 203-223, doi:10.1016/0022-1694(90)90150-V, 1990.

Zhang, Q., Fu, B., Chen, L., Zhao, W., Yang, Q., Liu, G., and Gulinck, H.: Dynamics and driving factors of agricultural landscape in the semiarid hilly area of the Loess Plateau, China, Agr. Ecosyst. Environ., 103, 535-543, doi:10.1016/j.agee.2003.11.007, 2004.

Zhu, T., Cai, Q., and Zeng, B.: Runoff generation on a semi-arid agricultural catchment: field and experimental studies, J. Hydrol., 196, 99-118, doi:10.1016/S0022-1694(96)03310-0, 1997. 